\title{
Effect of Temperature on the Kinetic Behaviour of Polyphenol Oxidase and Peroxidase in Fresh-cut Lettuce
}

\author{
Ana Belen Martin-Diana \\ Technological University Dublin, anabelen.martindiana@tudublin.ie \\ Daniel Rico \\ Technological University Dublin, daniel.rico@tudublin.ie \\ Catherine Barry-Ryan \\ Technological University Dublin, Catherine.Barryryan@tudublin.ie
}

See next page for additional authors

Follow this and additional works at: https://arrow.tudublin.ie/tfschafart

Part of the Food Science Commons

\section{Recommended Citation \\ Martin-Diana, A. B., Rico, D., Barry-Ryan, C., Mulcahy, J., Henehan, G. T. M. and Frias, J. Effect of Temperature on the Kinetic Behaviour of Polyphenol Oxidase and Peroxidase in Fresh-cut Lettuce, Acta horticulture, 687, 2005, DOI: 10.21427/d7bnOv}

This Article is brought to you for free and open access by the School of Culinary Arts and Food Technology at ARROW@TU Dublin. It has been accepted for inclusion in Articles by an authorized administrator of ARROW@TU Dublin. For more information, please contact arrow.admin@tudublin.ie, aisling.coyne@tudublin.ie, gerard.connolly@tudublin.ie.

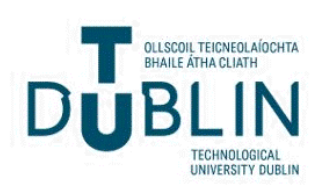


Authors

Ana Belen Martin-Diana, Daniel Rico, Catherine Barry-Ryan, Jemina Mulcahy, Gary Henehan, and Jesus Maria Frias

This article is available at ARROW@TU Dublin: https://arrow.tudublin.ie/tfschafart/135 


\title{
Effect of Temperature on the Kinetic Behaviour of Polyphenol Oxidase and Peroxidase in Fresh-cut Lettuce
}

\author{
A.B. Martín-Diana, D. Rico, C. Barry-Ryan, J. Mulcahy, G.T.M. Henehan and J. Frías \\ School of Food Science and Environmental Health, Postharvest Technology Unit \\ Dublin Institute of Technology, Cathal Brugha Street, Dublin 1 \\ Ireland
}

Keywords: salad-cut lettuce, heat-shock, browning, photosynthetic tissue, vascular tissue

\begin{abstract}
Activity levels for polyphenol oxidase (PPO) and peroxidase (POD) enzymes were exanimate in crude extracts and showed significantly higher values in photosynthetic tissue than in vascular tissue. Time courses at $50^{\circ} \mathrm{C}$ showed a rapid loss of POD activity and a similar but slower loss of PPO activity in all tissue while incubations at $4{ }^{\circ} \mathrm{C}$ and $25^{\circ} \mathrm{C}$ showed no significant loss of activity over the same time period. The thermal treatment of the extracts $\left(50^{\circ} \mathrm{C}\right)$ caused a decrease in the PPO and POD activities over time, in all the samples. PPO had less dependence on temperature than POD. The model prediction for PPO and POD for the first one minute at $50{ }^{\circ} \mathrm{C}$ has little effect on either enzyme with the loss of $\sim 6 \%$ of the total activity. Minimal processed lettuce washed at $50{ }^{\circ} \mathrm{C}$ and stored at $4^{\circ} \mathrm{C}$ during 10 days showed significantly lower PPO and POD activity throughout the storage period than those washed at $4^{\circ} \mathrm{C}$ and $25^{\circ} \mathrm{C}$ in the same conditions.
\end{abstract}

\section{INTRODUCTION}

Enzymatic browning is one of the most devastating reactions occurring to many minimally processed vegetables. Lettuce is highly susceptible to browning: Russet spotting (RS) is one of the disorders that appear in Iceberg lettuce and the enzymes peroxidase and polyphenol oxidase have been implicated both directly and indirectly in this process (Ke and Saltveit, 1989). Browning can adversely affect flavour and nutritional value. Bleaching treatments, in order to inactivate or inhibit the browning process, has been developed in vegetables; the most common method is the use of hot water alone or associated with salts or acids (Kidmose and Martens, 1999).

The first objective in this study was to analyse the PPO and POD activity in different parts of the lettuce, the commercial fresh cut Iceberg lettuce has very varied vascular and photosynthetic tissue. The second was to analyse the enzymatic activity kinetics of the peroxidase (POD) and polyphenol oxidase (PPO) in crude extract, isolated from Iceberg lettuce, and the effect of thermal treatment on these enzymes. The last objective was to analyse the enzymatic kinetics of PPO and POD in lettuce when stored at $4{ }^{\circ} \mathrm{C}$, previously treated at different temperatures $\left(4{ }^{\circ} \mathrm{C}, 25^{\circ} \mathrm{C}\right.$ and $\left.50^{\circ} \mathrm{C}\right)$ and to compare these with those obtained from the extracts.

\section{MATERIALS AND METHODS}

Iceberg lettuce (Lactuca sativa sp.) samples were prepared using a standard process. Washing treatment of lettuce was performed by immersion of the salad-cut lettuce in a distilled water solution at $4{ }^{\circ} \mathrm{C}, 25^{\circ} \mathrm{C}$ or $50^{\circ} \mathrm{C}$. The vegetables were dipped in water at the chosen temperature for $1 \mathrm{~min}$ with constant agitation and dried for $5 \mathrm{~min}$ using a salad spinner. The processed vegetables $(\sim 100 \mathrm{~g})$ were packed in bags $(200 \times 320$ $\mathrm{mm}$ ) made of $35 \mu \mathrm{m}$ thick oriented polypropylene (OPP) (Amcor Flexibles, United Kingdom). For time course experiments fresh Iceberg lettuce was purchased on the day of the experiment. The lettuce head was separated into two halves; the upper half (Top) and the lower part (Bottom). Each part was separated into two tissue types, photosynthetic (leaf) and vascular (rib) using a sharp stainless steel knife. For the minimal processed lettuce after the treatment were stored 10 days at $4{ }^{\circ} \mathrm{C}$. 


\section{Polyphenol Oxidase and Peroxidase Activity}

10 grams of lettuce was homogenized and placed in sodium phosphate buffer, $\mathrm{pH}$ 6.5 containing $50 \mathrm{~g} / \mathrm{L}$ polyvinylpyrrolidone. The homogenate was then centrifuged (Sigma $2 \mathrm{~K} 15$, Germany) at $12,700 \mathrm{~g}$ at $4{ }^{\circ} \mathrm{C}$ for 30 minutes filtered and the extracts were stored on ice, in the dark, until use. These extracts were used for the determination of PPO and POD enzymes.

PPO activity was assayed spectrophotometrically (Agilent. 8453-uV-visible spectroscopy system, Germany) by following catechol oxidation at $400 \mathrm{~nm}$ and $25{ }^{\circ} \mathrm{C}$ (Tan and Harris., 1995). POD activity was assayed spectrophotometrically at $485 \mathrm{~nm}$ and $25{ }^{\circ} \mathrm{C}$ using hydrogen peroxide $(1.5 \%)(\mathrm{v} / \mathrm{v})$ as the oxidant in the presence of p-phenylenediamine.

\section{Kinetics of Enzyme Activity at Different Incubation Temperatures}

Aliquots $(1 \mathrm{ml})$ of the homogenates made from different parts of the lettuce (top/bottom) and different tissues (vascular and photosynthetic) were transferred to plastic eppendorf tubes. The samples were incubated in a circulating water bath (Lauda E-300, Germany) at $50{ }^{\circ} \mathrm{C}$ or placed in a versatile Environmental Test Chamber (model, MLR350 , Sanyo, Japan) at $25^{\circ} \mathrm{C}$ and $4{ }^{\circ} \mathrm{C}$. Aliquots were removed each hour over a six hour period, cooled on ice, and assayed for PPO and POD activity.

\section{Thermal Inactivation Studies}

A crude extract prepared from a whole lettuce sample (without segregation of tissues) was incubated at $50{ }^{\circ} \mathrm{C}, 65^{\circ} \mathrm{C}$ and $75^{\circ} \mathrm{C}$ for 3600 seconds in a circulating water bath. Aliquots were removed as described above at 1, 5, 10, 20, 30, 40 and 50 minutes and assayed for PPO and POD activity.

\section{First Order Model}

The activation energies $(\mathrm{Ea})$ for PPO and POD were determined using a first order model with an Arrhenius temperature dependence of the rate constant (1), using data from three temperatures $(50,65 \text { and } 75)^{\circ} \mathrm{C}$.

$$
\text { Enzn }=\exp (-\exp (1 \mathrm{lrc} \text { tr }) * \exp (-\mathrm{Ea} / \mathrm{R} *(1 / \mathrm{T}-1 / \mathrm{Tr})) * \text { time })
$$

Where Enzn: normalised activity of PPO or POD, Ea: activation energy (KJ $\mathrm{mol}^{-1}$ ), R: gas constant $=8.3144 \times 10-3 \mathrm{KJ} \mathrm{mol}^{-1} \mathrm{~K}^{-1}$, Tr: reference temperature (333 Kelvin), T: experimental temperature $(\mathrm{K}), \mathrm{lrc}$ tr: the logarithm of reaction constant at the reference temperature $\left(\mathrm{min}^{-1}\right)$

\section{Statistical Analysis}

Statgraphics software (version 2.1; Statistical Graphics Co., Rockville, USA) and R software (R Development Core Team, 2004) were used in the study.

\section{RESULTS}

\section{Kinetics of PPO and POD Activity at Different Temperatures}

The Fig. 1 shows the effect of temperature on the enzymes in crude extracts most closely approximates the effect of temperature on whole lettuce. PPO and POD activities were examined in crude extracts from top and bottom halves of the head of lettuce and in vascular and photosynthetic tissues from each half. Significantly $(p<0.05)$ higher activity values were found in extracts from the bottom half of the head of lettuce than in the top half for both enzymes (Fig. 1 and 2). It was also observed that PPO and POD activities were significantly higher $(p<0.05)$ in photosynthetic tissue (leaf) than in vascular tissue (rib) (Fig. 1 and 2). This latter finding is consistent with data of Heimdal et al., (1994) and Vamos-Vigyazo (1981), which attributed the higher activity in photosynthetic tissue to the location of the PPO and POD in the thylakoid membrane of the chloroplasts. PPO and POD in lettuce tissue extracts incubated at $50{ }^{\circ} \mathrm{C}$ for 6 hours (Fig. 1 and 2) showed 
different behaviour to PPO and POD in extracts incubated at $4{ }^{\circ} \mathrm{C}$ and $25^{\circ} \mathrm{C}$, regardless of the type of tissue (leaf/rib) and the position in the head (top/bottom). PPO activity at 50 ${ }^{\circ} \mathrm{C}$ gradually decreased over the six hour incubation period in all the samples during storage (Fig. 1). Only a residual activity $(\sim 3 \%)$ remained at the end of the 6 hour storage period. Thus, prolonged exposure to elevated temperatures causes loss of PPO activity in crude extracts. When the same experiment was carried out monitoring POD activity (Fig. 2 ), over a six hour period, a similar pattern was observed, with a much faster loss of activity at $50{ }^{\circ} \mathrm{C}$ than the PPO. More than $95 \%$ of POD activity was lost after the first hour of incubation, with looses around 30 and $50 \%$ in the case of the PPO for the same incubation time. Interestingly, for samples incubated at $4{ }^{\circ} \mathrm{C}$ and $25{ }^{\circ} \mathrm{C}$, the activity of both enzymes increased up to 4 hours, and then started to decrease to initial values or below, meanwhile at $50^{\circ} \mathrm{C}$ decreased from the beginning of the thermal incubation.

\section{Thermostability Studies}

In order to more completely characterise the heat lability of PPO and POD, detailed thermostability studies were carried out at higher temperatures for shorter time periods. Extracts of non-processed lettuce were used for these studies with no tissue differentiation, as the previous time course experiments indicated enzyme from different tissues had similar degradation kinetics at $50^{\circ} \mathrm{C}$. When PPO extracts were heated at $50{ }^{\circ} \mathrm{C}, 65^{\circ} \mathrm{C}$ and $75^{\circ} \mathrm{C}$ for 1 hour (Fig. 3I) the percentage of activity remaining was $72 \%$, $31 \%$ and $0 \%$ respectively. For all temperatures, an initial rapid decrease in activity was observed followed by a slower loss of activity with time.

The same thermostability study was carried out for POD in samples heated at $50{ }^{\circ} \mathrm{C}, 65^{\circ} \mathrm{C}$ and $75^{\circ} \mathrm{C}$ for 1 hour (Fig. 3II). Enzymatic activity decreased much more rapidly than for PPO. For all temperatures $>90 \%$ inactivation was observed within 2000 seconds. The bulk of POD activity was lost within 5 minutes even at the lowest treatment temperature $\left(50^{\circ} \mathrm{C}\right)$.

\section{Modelling of Thermal Inactivation Kinetics of PPO and POD}

The general shape of the thermal inactivation curves was exponential, indicating a first order process (Fig. 4). The data were modeled using a first order relationship where the rate constant is temperature dependant. The exponential model showed that PPO $\left(\mathrm{Ea}=110,72 \pm 13.63 \mathrm{KJ} \mathrm{mol}^{-1}\right)$ was much less sensitive to high temperatures than POD (Ea $=51.73 \pm 9.66 \mathrm{KJ} \mathrm{mol}^{-1}$ ). The grey-scale regions (percentage of remaining activity) showed a clearly different distribution for PPO and POD. For POD (Fig. 4I) the beginning of the loss of activity (clearest grey-region) appeared at lower temperatures and shorter times. For PPO, by contrast, there was no activity lost (white region) for times shorter than 300 seconds and temperatures under $65^{\circ} \mathrm{C}$ (Fig. 4II).

\section{PPO and POD Activity in Minimally Processed Iceberg Lettuce}

PPO activity (Fig. 5I) in minimally processed lettuce washed at $50{ }^{\circ} \mathrm{C}$ had significantly $(\mathrm{p}<0.05)$ lower values than samples washed at $4{ }^{\circ} \mathrm{C}$ or $25{ }^{\circ} \mathrm{C}$. These lower values were particularly observed from day 6 to 10 , where the PPO activity levels in lettuce washed at $50{ }^{\circ} \mathrm{C}$ stayed constant while increased in the samples treated at $4{ }^{\circ} \mathrm{C}$ and $25{ }^{\circ} \mathrm{C}$. These results were in agreement with the others authors who described that maximum PPO values are observed immediately after the shredding and during the last days of shelf-life (Cantos et al., 2001). It is of considerable interest that this activity increase was not observed in samples washed at $50{ }^{\circ} \mathrm{C}$. When POD activity was analysed, it was found that samples washed at $50{ }^{\circ} \mathrm{C}$ had lower activity throughout storage (Fig. 5II), showing similarities with the PPO.

These results clearly showed that heat-shock reduced the activity of PPO and POD in minimally processed lettuce. Moreover, this reduction is maintained throughout storage. However, a substantial amount of activity of both enzymes remains even after storage for ten days at $4{ }^{\circ} \mathrm{C}$. Significant differences in PPO and POD activity were observed in different tissues and positions in the head of lettuce. 


\section{DISCUSSION}

Kinetics studies showed that POD is a more heat labile enzyme than PPO in crude extracts. Different activities of the browning-related enzymes were found in vascular and photosynthetic tissues. However, no significantly $(p>0.05)$ different thermal behaviour was observed between enzymes from different tissues.

Thermoestability studies on the extract showed an initial rapid loss of activity followed by a slower decline, which could be due to the presence of different isoenzyme forms (Whitaker, 1995) of PPO with different thermolability profiles. Alternatively, it could be due to the formation of a less active (damaged) form of PPO as a result of the heat treatment.

POD showed more sensitive to elevated temperatures than PPO. This finding confirms the time course data on the sensitivity of POD to heat treatment. Several authors support the idea of a synergistic activity between POD and PPO enzymes; the products of POD are used by the PPO so a decrease in POD activity can produce a decrease in the substrate available for PPO (Castañer et al., 1999).

It is of interest to note that both enzymes, PPO and POD (Fig. 3), showed a transient activation of approximately $10-15 \%$ at the beginning of the incubation at $50{ }^{\circ} \mathrm{C}$ followed afterwards by an activity decline. This activation was reproducible over 16 replicates and was more pronounced for POD than PPO. This behaviour has been explained by Carrea et al., (1982), explained the presence of an activation period by the restoration of essential thiol groups on the enzyme.

From the data obtained from the mathematical model, it is clear that heating at 50 ${ }^{\circ} \mathrm{C}$ for 5 minutes will completely eliminate POD activity while PPO is still at $91 \%$ of its original activity. Even heating at $70{ }^{\circ} \mathrm{C}$ for 5 minutes still leaves $62 \%$ of original PPO activity intact. Thus, there is no significant benefit in the use of temperatures higher than $50{ }^{\circ} \mathrm{C}$ for inactivation of these enzymes. Moreover, the possibility of product deterioration is higher at the high temperatures such as lost of texture and nutritional value (Kidomose and Martens, 1999). It may not be necessary to inactivate both PPO and POD to reduce browning reactions since there is a possible synergistic relationship between these enzymes (the products of POD are used as substrates by PPO). Therefore, a decrease in POD activity will decrease the substrate available for PPO (Castañer et al., 1999), thus reducing its role in browning reactions.

The model inactivation prediction for both PPO and POD shows that one minute at $50^{\circ} \mathrm{C}$ has little effect on either enzyme with losses of $\sim 6 \%$ of the total activity. These results indicate that the effect of heat-shock $\left(1\right.$ minute, $\left.50{ }^{\circ} \mathrm{C}\right)$ in reducing browning reactions cannot be directly ascribed to complete or even substantial inactivation of PPO and POD. This observation is based on data derived from crude extracts. However, the stability of these enzymes in whole tissues is likely to be even higher in whole tissues.

In fresh-cut lettuce the effect of heat-shock might not have occurred through the inactivation of particular enzymes but rather the general shifting in protein synthesis, reducing the synthesis of enzymes in different pathways (Salveit, 2000). This is supported by the abolition of the increase in PPO activity seen at $4{ }^{\circ} \mathrm{C}$ and $25^{\circ} \mathrm{C}$ when lettuce was heat-shocked at $50{ }^{\circ} \mathrm{C}$. Differences between tissues in PPO and POD indicate that some regions of the lettuce may be more susceptible to browning than others. It is possible that if, during minimal processing, tissues were segregated according to their PPO and POD activity they might show differences in browning quality retention.

\section{CONCLUSION}

The main conclusion from these studies is that heat-shock treatment of minimally processed lettuce causes a reduction in the browning-related enzymes PPO and POD activity during storage. The thermal stability studies showed heat-shock browning reduction effect not caused as a direct denaturation of PPO or POD since 1 minute at 50 ${ }^{\circ} \mathrm{C}$ only caused a $6 \%$ loss of activity in crude extracts. Further investigations for comprehensively understanding of the effect of heat-shock on the synthesis of these enzymes are suggested. 


\section{ACKNOWLEDGEMENTS}

This research was supported by a Technological Sector Research grant (2002-2006).

\section{Literature Cited}

Cantos, E., Espin, J.C. and Tomas-Barberan, F.A. 2001. Effect of wounding on phenolic enzymes in six minimally processed lettuce cultivars upon storage. J. Agric. Food Chem. 49(1): 322-30.

Carrera, G., Bovara, R., Pasta, P. and Cremonesi, P. 1982. The effect of Hofmeister anions and protein concentration on the activity and stability of some immobilized NADdependent dehydrogenases. Biotchnol. Bioeng. 24:1-7.

Castaner, M., Gil, M.I., Ruiz, M.V., and Artes, F. 1999. Browning susceptibility of minimally processed baby and romanie lettuces. Eur. Food Res. Technol. 209:52-56.

Heimdal, H. Larsen, L.L. and Poll, L. 1994. Characterization of polyphenol oxidase from photosynthetic and vascular lettuce tissues (Lactuca sativa). J. Agric. Food Chem. 42:1428-1433.

Ke, D. and Saltveit, M.E. 1989. Wound-induced ethylene production, phenolic metabolism and susceptibility to russet spotting in Iceberg lettuce. Physiol. Plant. 76:412-418.

Kidmose, U. and Martens, H.J. 1999. Changes in texture, microstructure and nutritional quality of carrot slices during blanching and freezing. J. Sci. Food and Agric. 79:17471753.

Salveit, M. 2000. Wound induced changes in phenolic metabolism and tissue browning are altered by heat-shock. Postharvest Biol. and Technol. 21:61-69.

Tan, B.K. and Harris, N.D. 1995. Maillard products inhibit apple polyphenol oxidase. Food Chem. 53:267-273.

Vamos-Vigyazo, L. 1981. Polyphenol oxidase and peroxidase in fruits and vegetables. Crit. Rev. Food Sci. Nutri. 15:49-127.

Whitaker, J.R. and Lee, C.Y. 1995. Recent advances in chemistry of enzymatic browning: an overview. p.2-7. In: Lee \& Whitaker, J.R. (eds.), Enzymatic browning and its prevention. ACS Symp. Ser. 600, Washington. 


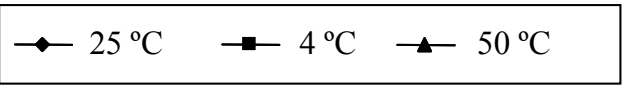

(I)

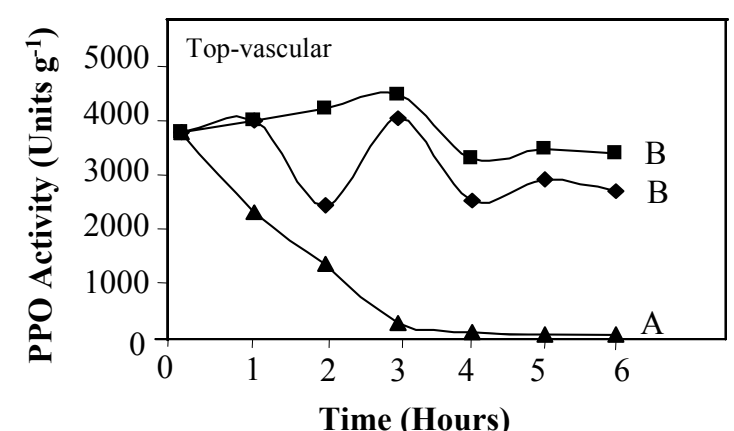

(III)

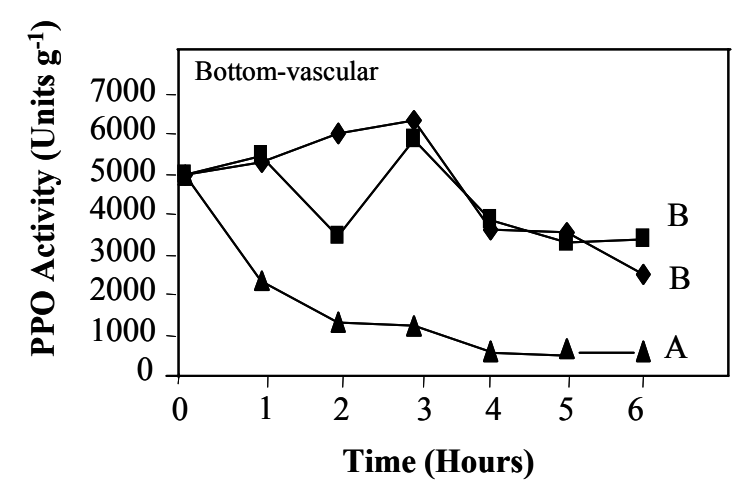

(II)

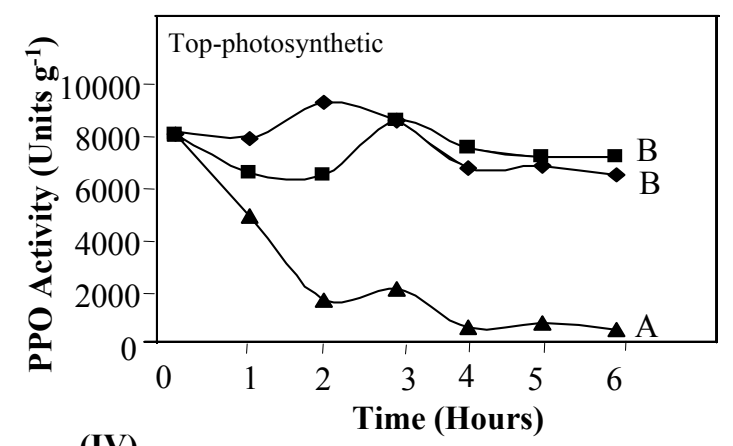

(IV)

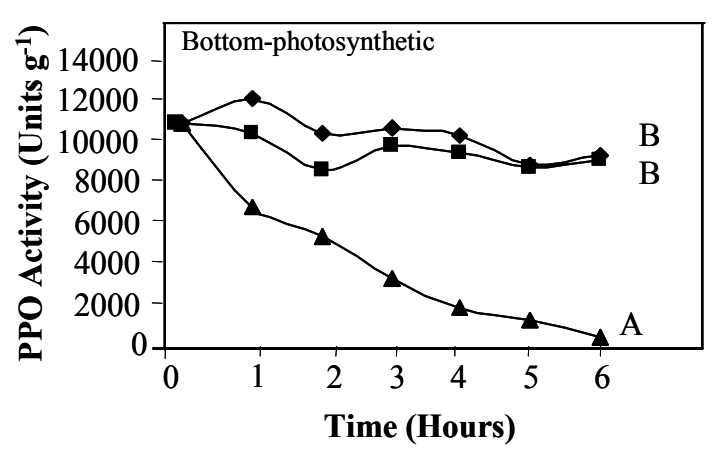

* Curves that are significantly different are designated with different letters $(p<0.05)$

Fig. 1. Polyphenol oxidase activity as a function of incubation temperature. Top vascular tissue (I); top photosynthetic tissue (II); bottom vascular tissue (III) and bottom photosynthetic tissue (IV). 


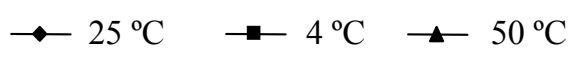

(I)

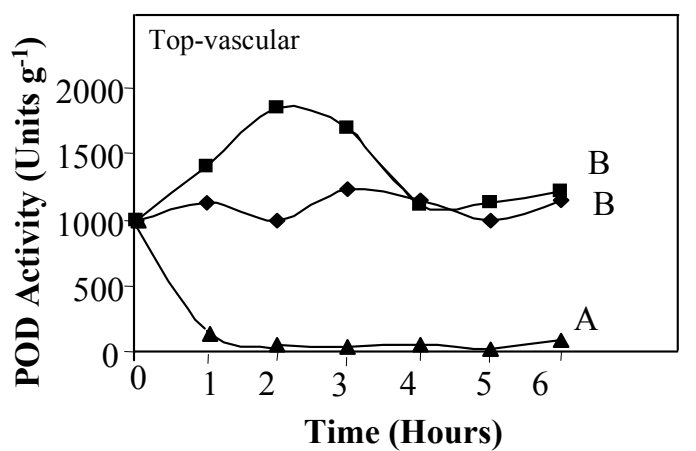

(III)

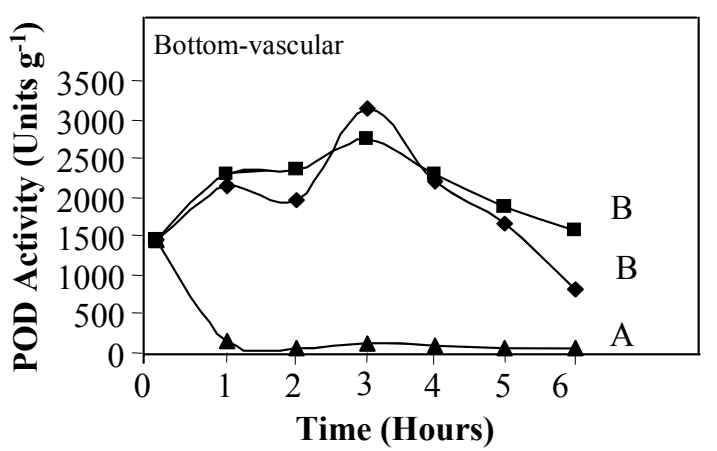

(II)

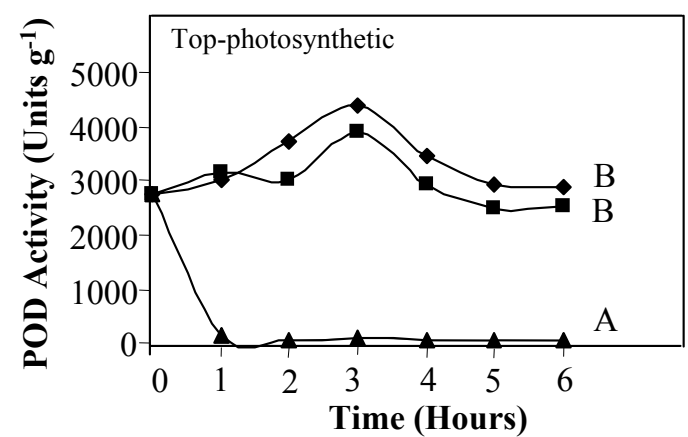

(IV)

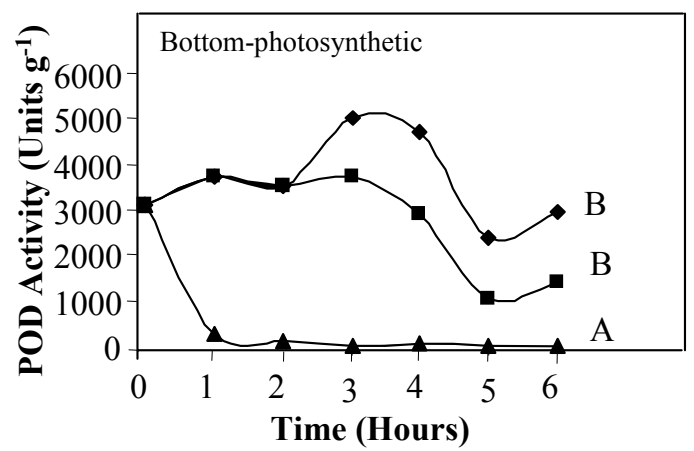

* Curves that are significantly different are designated with different letters $(p<0.05)$

Fig. 2. Peroxidase activity as a function of incubation temperature. Top vascular tissue (I); top photosynthetic tissue (II); bottom vascular tissue (III) and bottom photosynthetic tissue (IV).

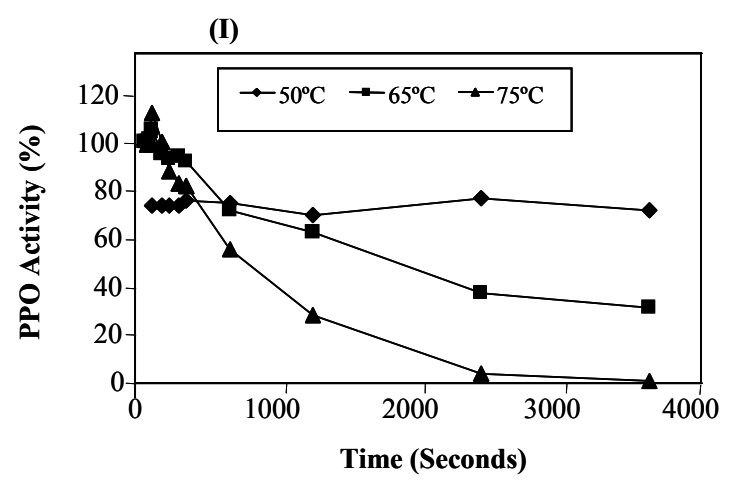

(II)

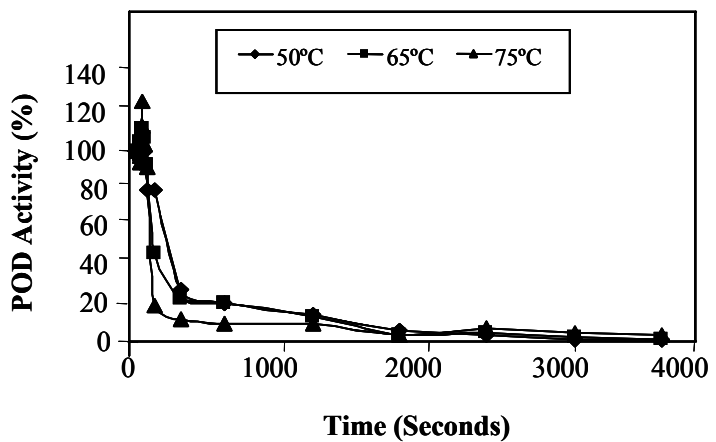

Fig. 3. Thermal inactivation profiles of polyphenol oxidase (I) and peroxidase (II) activity $(\%)$ at $(50,65 \text { and } 75)^{\circ} \mathrm{C}$ in crude extracts over 1 hour (3600 seconds). 
(I)

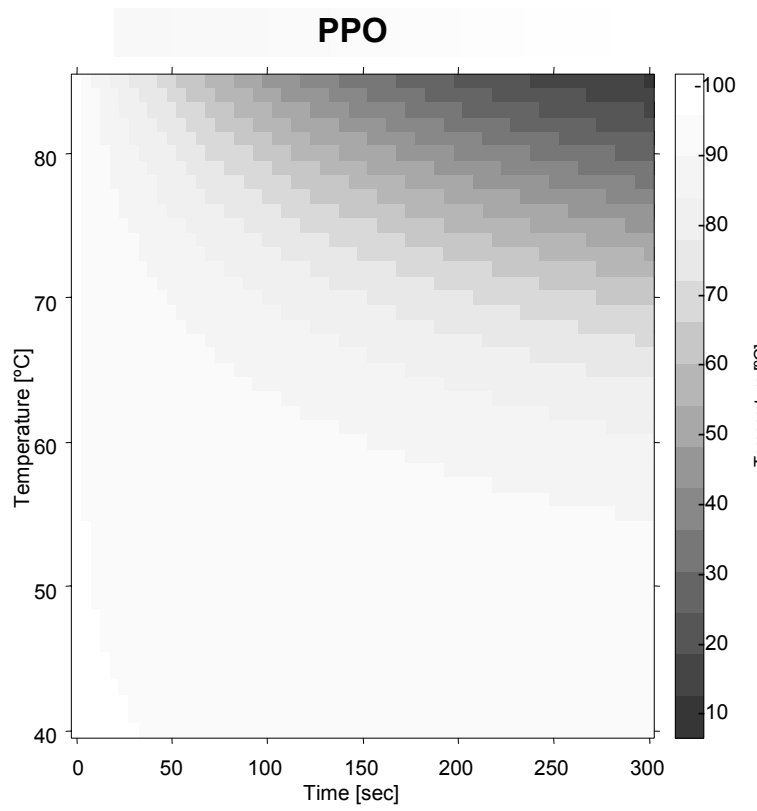

(II)

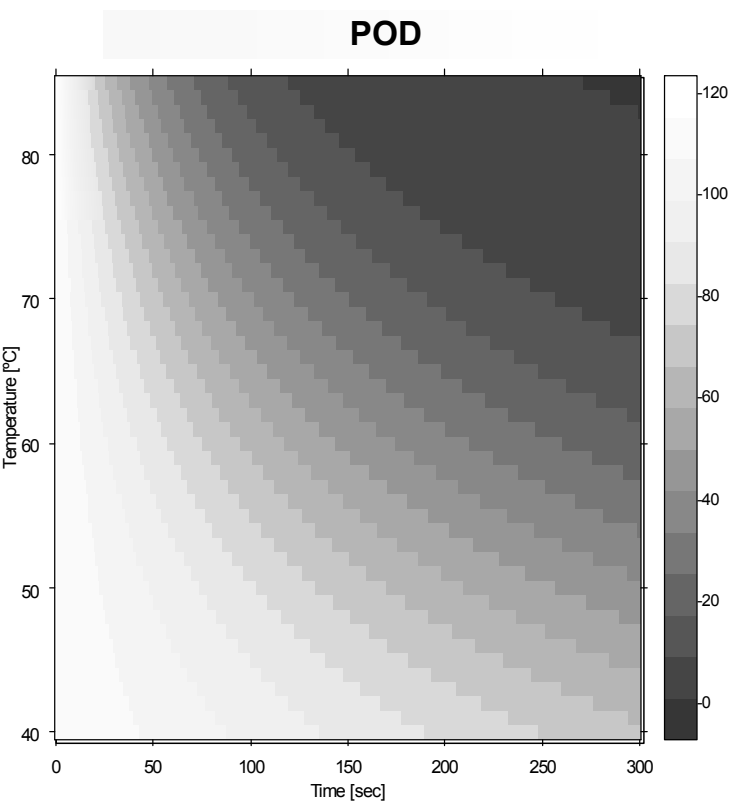

Fig. 4. Simulated polyphenol oxidase (II) and peroxidase (I) thermal inactivation using a first order model with a temperature dependant rate constant using data from three temperatures $(50,65$ and 75$){ }^{\circ} \mathrm{C}$. The darker areas of the contour plot represent the lowest enzyme activities.

(I)

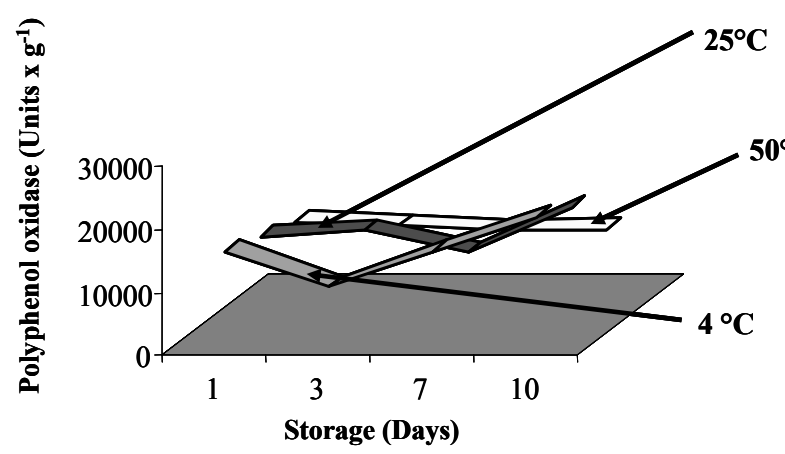

(II)

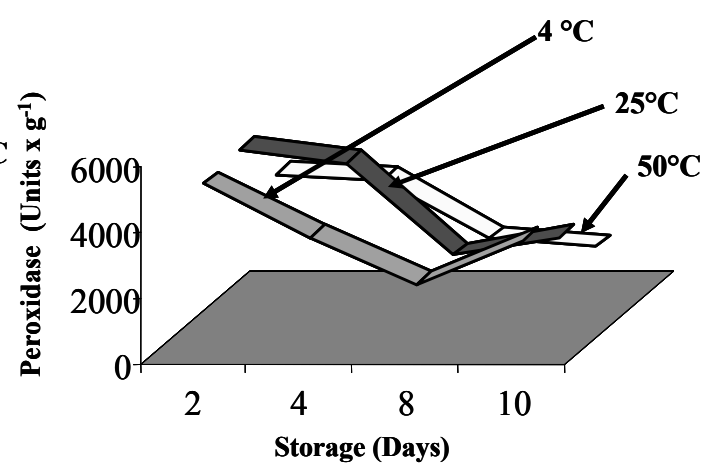

Fig. 5. Effect of washing temperature treatments at $4{ }^{\circ} \mathrm{C}, 25{ }^{\circ} \mathrm{C}$ and $50{ }^{\circ} \mathrm{C}$ on the polyphenol oxidase (I) and peroxidase (II) activity in minimally processed saladcut Iceberg lettuce during storage for 10 days at $4{ }^{\circ} \mathrm{C}$. 